\title{
Political Relations of Australia with the United States: 2000-2017
}

\author{
Mieczysław Sprengel \\ Collegium luridicum Novum \\ Faculty of Law and Administration \\ e-mail: sprengel@interia.pl
}

\section{Abstract}

Relations between Australia and the United States have developed for long time notably during World War II. Over the following decades, cooperation has become more intense as Australians adopt many cultural patterns from the Americans. Australia declared and supported US presidents in military operations, which is why some have called Australia, America's sheriff for working to stabilize this part of the world. One cannot overlook the personal arrangements between leaders that help shape the dynamic of deepening the mutual relations these two nations. Donald Trump's personal interactions' with the Prime Ministers of Australia play a significant role in this regard.

Keywords: Australia, United States America, Japan, political relations. 


\section{Introduction}

In order to analyze the political relations between Australia and the United States in the years 2000-2017, one must at least reach out and outline the changes that have occurred on the political scene in the world after the Second World War.

After the Second World War, Americans wanted to obtain comprehensive military-administrative control in Japan. In this way, a barrier was created against the expanding communist regime. After a longer stay of US troops in the territory of the Japanese state, General Douglas MacArthur in a New Year's speech on January 1, 1950, stated that: "Japan may establish a defensive alliance and join the UN, or rely on US troops for self-defense" (Wilanowski, 264). At the end of World War II, the United States themselves proposed the creation of a system of international economic organizations that would help in the reconstruction of destroyed countries after the war. Another role of these organizations was to improve the functioning of links between different countries.

Representatives of the Australian government believed that the contribution of their army to defeating the enemy should guarantee their status at the table during the peace conference. In fact, Australia was removed from the most important negotiations in Cairo, Yalta and Potsdam. Peace agreements were concluded in such a way as to ensure control of the world, above all the United States, Great Britain and the USSR. "The Canberra Times" reported that after short visits of Prime Minister Joseph Benedict Chifley in the United Kingdom, Japan and the USA, Australia proceeded to secure itself in the event of another war (Industrial expansion plans. The Canberra Times 1).

Australia was dissatisfied with the actions of the United Kingdom, which took action with the United States to cooperate more closely in Europe. In this situation, in January 1944, it signed an ANZAC defense pact with New Zealand - without any consultation or informing the British side of this fact. As a result of signing this document, Australia considered itself as a defender of the British civilization in the Pacific. Despite British promises, Australia was not invited to San Francisco for a ministerial conference in April 1945. It was also surprising for Australian leaders that the conditions for capitulation agreed at the Potsdam conference at the end of July 1945 were learned from the press. As a result, the Australians protested and did not send any delegation to the Japanese surrender ceremony that took place on September 2, 1945 in the Gulf of Tokyo. At that time, only symbolically, Australia had to be represented by Great Britain. In contrast, Australians directly with the Americans demanded the signing of capitulation documents and the acceptance of the full composition of the Council of Foreign Ministers for the Pacific and the Far East. Minister Herbert Evatt issued a letter to the British Government on August 9, 1945, in which he stressed the indifference of Great Britain and demanded that Australia should be granted full negotiation status. The English did 
not respond to the letter - subsequently the political dialogue between the two countries began in the press (Meaney, 6-9). Against this background, relations with the United Kingdom gradually faded and the United States became a new partner.

\section{New partner of Australia: United States}

Unquestionably, an important partner of Australia was the United States. Its meaning is described by Edward Haliżak in the following words: "The American doctrine of containment in the Asia-Pacific region is often assessed from the point of view of the lost Vietnam war. Without diminishing this fact, it should be noted that throughout the Cold War period, the US remained the main guarantor of Western interests in the region, as evidenced by the fact of direct involvement in two regional armed conflicts (Korea and Vietnam) (Haliżak, 137)".

The greatest achievements of the "containment doctrine" emerged in the economic sphere. As already mentioned, ensuring the security of Japan and Taiwan and South Korea gave them opportunities for rapid development. In addition, American investments and easy access of these countries to the US market stimulated economic development. The growing importance of American economic interests in foreign policy towards the Asia-Pacific region was marked in the 1970s, when the first trade disputes with Japan and later with other countries appeared. At this point, politicians and business circles understood that the region's economy could compete with the US economy. In the late 1970s, US policy changed in the approach to the institutionalized form of regional economic cooperation. Senator John Glenen, chairman of the Subcommittee on East Asian and Pacific Affairs of the Senate Committee on Foreign Affairs, contributed to this. Glenn has dealt with the possibilities of developing regional economic cooperation since 1978. At the request of the Congress, professors Peter Drysdale and Hugh Patrick prepared a report in which they pointed out the need to set up an organization called the Organization for Pacific Trade and Development (OPTAD), modeled on the OECD.

Already in the early 1980s, US trade with the Asia-Pacific region matched commercial trade with European countries. In connection with the economic ties of the United States with the countries of the Asia-Pacific region, the approach of American diplomacy to these countries changed. Edward Haliżak wrote that it was not possible to treat these countries only in terms of defense against communism (Haliżak, 139). The deterrence strategy was no longer valid, but new economic challenges arose. In the face of these events, a new strategy was created in which the US found itself in the region on the principle of an important member in the political and strategic structure of the region. The US presence was supposed to be economic, political and culturally civilizational. The interest of the United States 
in the Asia-Pacific region in a different dimension than just military has brought about the elevation of this region. It became an area for American investments and exports, which generated profits for both sides.

\section{Time to fight terrorism together}

In the Asia-Pacific region, apart from economic issues, political problems were very important. There has not always been a political unanimity of states in the context of common interests, but in opposing terrorism many states showed solidarity.

A month before the terrorist attack in the United States, in August 2001, Prime Minister John Howard visited Japan, where he held talks with members of the Japanese government and the private sector. They talked about bilateral relations with Japanese Prime Minister Koizumi and Foreign Minister Makiko Tanaka. These talks were aimed at calming Japanese partners after the talks of the Australian side (Defense Minister Peter Reith and Foreign Minister Alexander Downer) with the American side (Secretary of State Colin Powell and Secretary of Defense Donald Rumsfeld and Pacific Commander in the Pacific Admiral Dennis Blair) on building a new defense forum. As a result of publicizing the whole case by journalists, the Australian government had to calm down not only Japan and South Korea, but also suspicious China. During this visit, Howard assured Japan that he was not building an exclusive US-Australian bloc.

During the terrorist attack on New York and Washington, Prime Minister Howard paid an official visit to the United States. In contrast to not very pleasant contacts with President Bill Clinton, Howard had a good relationship with George W. Bush. During a visit in 2001, he was warmly welcomed by President Bush and other government officials, including US Secretary of State Powell and Defense Secretary Donald Rumsfeld. Howard's words of friendship with the United States were immediately put to the test. The September 11, 2001 events in New York set Australia in the face of US obligations under the ANZUS agreement. After Howard's return to Australia, in his decisions the parliament referred to the ANZUS treaty signed 50 years earlier, which was used in 2001 for the first time in the activities of Australia for the United States. The attack of troops on Iraq without the international involvement of UN forces caused a wave of protests in Australian cities, similar to the Vietnam War (Eccleston 4). Prime Minister Howard hoped that the consequences of a terrorist attack on the United States would be serious and would trigger further threat. Despite the two-party support in the Australian parliament, Howard cautiously spoke about expanding cooperation with the US and counteracting terrorism.

The threat of terrorism at the beginning of the 21st century has caused drastic changes in international politics in terms of security. The dynamics of 
Australian-American relations after 2001 was also linked to these events. Without taking into account the military dominance of the US in the world, radical terrorist groups began to operate across state borders. NATO's offer of military assistance in the fight against terrorists was rejected by Washington. The United States feared that multilateral NATO troops could delay US operations. Therefore, the American side was reluctant to accept support in military activities. However, Washington accepted the help of two permanent allies: Great Britain and Australia. After 10 days from October 7, 2001, i.e. from the action initiated against the Taliban, President Bush accepted Australian commitments to expose 1,550 soldiers to military operations. Howard informed Australian general Peter Cosgrove that he was authorized to act as part of American and coalition forces a coalition American action to disarm Iraq. Australian assistance was also focused on the deployment of Special Air Service (SAS) - where the Australian legion numbered 150 people. In this way, Australia joined the United Kingdom and the United States in a pre-emptive attack against the Taliban.

In addition to Australia's involvement in Iraq from the end of 2001, the Australian Defense Force (ADF) was represented in military operations in Afghanistan, Kyrgyzstan and the Gulf in a number of 850 to 1,300 soldiers. At the end of 2002, Australia withdrew its SAS legion from Afghanistan, which numbered 150 people. The legion was withdrawn despite evidence of increasing violence.

Australian journalist Michael Duffy claimed that Australia's support in the war against terrorism had not been great so far. He wrote that most of the hard work of Howard was left to American and British soldiers. Prime Minister John Howard was aware of this criticism and concerns about the Pentagon in relation to limited support from Australia. The Australian prime minister explained that its troops were involved at this time in other extraordinary coalition operations in East Timor and the Solomon Islands. At that time, Australian forces also participated in secret operations in the Middle East. Howard's government was reluctant to acknowledge a small contribution to the reconstruction and security of Afghanistan (Gurry, 227-229).

\section{Australia as a "deputy sheriff"}

A new impulse for action for Australia were the Bali bomb attacks. After September 11, 2001, the next largest terrorist act occurred in Bali - October 12, 2002, when the bombs exploded at the Sari Nightclub in Kuta Beach. At that time, 202 tourists died, including 88 Australians and 15 Japanese. The terrorist attacks also affected Australia's as an American ally. In addition, the domestic crisis in the Solomon Islands, Papua New Guinea and, to a lesser extent, Nauru, brought serious challenges to the Australian government. Canberra's foreign policy was now even 
more involved in the intervention. Howard's government stood out with its determination to support the US in the fight against terrorism (Serafin, 587). A few years before 2002, it was maliciously said that Australia was a "sheriff deputy," that is, the United States in the region, but since 2002, the parties have fully supported the fight against terrorism. Canberra has become the main ally supporting the peace process since 2002 (O'Keefe, 131).

Despite Australia's commitment to the cause, the Australian newspaper The Sydney Morning Herald on September 11, 2003, commented on the American war on terror as unsuccessful and unstable world peace. Apart from international comments, Howard admitted that the Taliban war did not bring the desired effect, on the contrary, it intensified the aggression of the opponent. Howard thought that the war would not last long and would not have occupation. There have been tensions based on these and other facts between Australia and the United States. Bush also admitted after three years from September 11, 2001 that he could wait for the end of the war on terror and added:, "I do not think we can win" (Bell, 31).

In spite of some misunderstandings, Howard's government defended from the middle of $\mathbf{2 0 0 2}$ the position of the United States on a pre-emptive attack on Iraq. Australian officials shared the view that one should not wait for a terrorist attack, but attack beforehand. In recognition of the position of Australia and the significance of the ANZUS pact, Prime Minister Howard was invited to give a speech at the United States Congress on June 12, 2002. During his speech, among others he said: "America has no better friend anywhere than in Australia." In spite of his support for the United States, Howard in September 2002 inquired in earnest what weapons were used and which (WMD) Iraq had. Assistance to the United States was expressed in the solidarity of Australian troops in the war with the Taliban and al-Qaeda in Afghanistan and in the work of secret Australian services in Pakistan. As a result of the special work of the military groups, it was discovered that in January 2002, al-Qaeda operating units in Southeast Asia were planning a terrorist attack in Singapore (Bell, 33).

In addition to Howard, full support for the Bush administration was given by Japanese Prime Minister Junichiro Koizumi. However, unlike the Australian side, which was bound by the ANZUS pact, the Japanese side was limited in its assistance to the United States by article 9 of the Japanese constitution. Koizumi took advantage of the Japanese's concerns about hostile North Korea and public support for the US and wanted to revise the constitution. However, it was not possible to change the constitution beyond the creation of a parliamentary committee in this matter. On December 11, 2001, the law on international peace was amended, which allowed the Japanese Self-Defense Forces (SDF) to participate in UN peacekeeping.

As a result of terrorist attacks, not only did the contacts between Australia and the United States strengthen, but also even more with Japan. At the turn of 
April and May 2002 in Australia, Prime Minister of Japan, Junichiro Koizumi, paid a visit to Australia. During the visit, among others, security issues were discussed. The terrorist attack on Bali strengthened Australia's position on the American attack on Iraq. The Australian government stressed that international legal norms do not keep pace in solving the threats to the modern world from terrorism (Sydney Morning Herald...). After some time, Howard unofficially admitted that without the UN's approval, such an action could not have majority support in Australia. In this situation, the Prime Minister of Australia sought to maintain a balance between support for the US and national unrest, resulting from the war against Iraq.

After September 11, 2001, international and regional communities had to determine on security. These issues concerned the United States and Australia as much as possible. Canberra, which had been interested in economic relations so far, had to agree and start cooperating in the field of regional security in the $21^{\text {st }}$ century. The White House played a central role in the area of security. Although the role of Australia in the region was significant due to the alliance with the United States, Canberra acted as a representative and as if it was an "agent" of America. In addition, the Australian Prime Ministers by engaging with Washington in the war against Afghanistan and Iraq and getting access to intelligence materials, gained a significant position in this regard. Relations between Australian Prime Minister Howard and President Bush were very correct and close at this time. Washington demanded close cooperation from its allies, sometimes omitting the UN (Bajkowski, Premier leci do Londynu, 4).Australia had no influence on the decisions taken in 2002 by the United States regarding the attack on Iraq.

The United States were more important than the UN, which Canberra does not have much impact on. Therefore, it should be assumed that Howard's first visit to Europe in 2002, since he was Prime Minister of Australia, concerned among others the presentation of argumentation for the acceptance by the European Union's member states of the foreign policy of American President Bush (Bajkowski, Emisariusz Busha?, 6). As a result of this attitude, Howard was called the "American sheriff" (Bajkowski, Forum Pacyfiku, 6). Despite the Australian involvement, Prime Minister Howard hoped that he would not come to war with Iraq and called on Bush to extend the inspection period in Iraq (Bajkowski, Stanowisko Howarda, 6). In addition, the mood in Australia was clearly opposed to the beginning of the Iraq war. In Australia, there had not been such big demonstrations since the Vietnam War (Bajkowski, Masowe demonstracje, 6). In total, over one million people demonstrated. Washington, on the other hand, adopted the supremacy of common supranational interests. There was no doubt that the strict political and defense links between Australia and America were an objective geopolitical necessity (Bajkowski, Spotkanie $w$ Waszyngtonie, 6). Additionally in the context of the threat of weapons of mass destruction, particularly in South-East Asia, Australia was 
convinced of maintaining good relations with Asia-Pacific countries (Bajkowski, Trzy zasadnicze tezy, 6).

In the face of terrorism, Australia was interested in security and closer cooperation with Washington. Talks were held in the triangle Australia, Japan, and the United States. Particularly, changes began quickly during Prime Minister Koizumi's reign.

In October 2003, the UN Security Council on the basis of Resolution 1511, recognized the multinational military formation as a stabilization mission. In this situation, operations carried out in Iraq took on a slightly different character, status and support by public opinion in Australia. Howard confirmed then that he would not take troops from Iraq until the task was completed (Sydney Morning Herald...). Despite this declaration, Australia's contribution to the occupation and reconstruction of Iraq was relatively small. Howard did not accept Bush's proposal of April 2003 to intensify the deployment of Australian troops in Iraq (Kitney). The Australian involvement was significantly exceeded not only by the United Kingdom, but also countries such as Italy, Poland, the Netherlands, Bulgaria and Denmark. In mid-July 2003, the Australian forces numbered 1370 soldiers. In September 2005, 450 additional soldiers were sent to protect the Japanese forces carrying out humanitarian work in the Al-Muthanna province. The involvement of Australian soldiers was less risky than the American and British ones. All in all, the US administration appreciated Australia's involvement in the process of entering Iraq. Howard himself was worried about Australia's security in the future, since he became a visible ally of the United States. Similarly, most Australians believed that a nation engaged in a mission in Iraq was at the same time a likely target for terrorists. The Australian Parliament justified the engagement of Australian troops to US operations in Iraq as a necessary decision to maintain the alliance with the United States. Critics of Australian involvement believed that the entry of Australian troops was unfounded and unnecessary. The alleged arsenal of weapons, in fact, did not exist.

Actions against terrorism were also discussed on September 21-22, 2005 in Washington with the participation of the American side. The meeting was attended by Henry Crumpton - representative of the US State Department for terrorism, Tadamichi Yamamoto - representative of the Ministry of Foreign Affairs of Japan, and Les Luck - Australian ambassador responsible for combating terrorism. During the talks, the situation of international terrorism and means of combating it was discussed. The security issue was also discussed at a meeting in Tokyo on October 23-24, 2005. At that time, the Japanese side was represented by Tsuneo Nishida (Deputy Minister for Foreign Affairs for administrative affairs), US side by Nicholas Burns (Undersecretary of State for Political Affairs) and Australian side by Michael L'Estrange (secretary of the Department of Foreign Affairs and Trade) (Mofa).

Another very important security meeting took place on March 18, 2006 in Sydney. The Foreign Minister of Japan Aso came to Australia. In a joint statement, 
Alexander Downer and Taro Aso announced a "partnership" between Australia and Japan based on democratic values, respect, friendship and common strategies. The meeting on security was held with the participation of the US party, US Secretary of State Condoleezza Rice. The meeting stressed the important role of the three states in maintaining global security, Australia, Japan and the United States. It was decided to build new relations between the countries, creating the "Building a Comprehensive Strategic Relationship." It was decided to strengthen the tripartite cooperation in the field of information exchange and evaluation of international and regional security problems. It should be emphasized that the tripartite dialogue between the US, Japan and Australia, which began at a higher state level in 2002, expressed the determination of these states to protect common strategic interests in promoting peace and stability in Asia-Pacific region. Minister Downer declared that construction of comprehensive strategic relations began. In addition, the Prime Ministers have set up the creation of various information exchange programs by 2006 (Mofa).

Since the 2003 agreement on combating terrorism, the most important element in addition to commercial matters were tripartite meetings of representatives of the US, Australian and Japanese authorities. The then Australian Ambassador to Japan, Tom Schieffer, stated in an interview given in early December 2005 that the joint work of the Japanese and Australians regarding security in the region was very important ("US keen on Japanese ties with Australia", The Australian. 2005). Security issues were presented by both countries at the ASEAN Regional Forum (ARF).

In addition to the Iraq issue between Australia and the United States, representatives discussed free trade, signing an agreement in August 2004, to be in effect beginning January 1, 2005. Mark Vaile, the Australian Trade Minister, treated this agreement as the commercial equivalent of the ANZUS Treaty. Some commentators even claimed that this agreement is a reward for the devoted service of Australian troops in Iraq. Minister Downer caused confusion in Washington when, during a visit to Beijing in 2004, he said that the terms of the ANZUS Treaty did not oblige Australia to help the United States in the event of a conflict over Taiwan. In addition, Howard stated that China could also purchase Australian uranium as long as it would be used for peaceful purposes (Blumenthal). The Howard government assumed that China would not threaten world security. In this matter, however, the United States was more cautious. Howard, however, felt that his policy had demonstrated the ability to maintain balance in relations with Asian neighbors and China, while simultaneously working closely with the United States (Shanahan).

The close relations between Australia and Japan also influenced Asia's integration to a large extent. Joint actions have contributed to ensuring peace and stability in the region. The conference also highlighted the importance of the new Trilateral Strategic Dialogue (TSD) signed with the United States on March 18, 2006 (Mofa). 
The visit of US Secretary of State Condolelezza Rice in March 2006 in Sydney mainly concerned tripartite talks, which were to ensure that China's rapid development and the rise of China's economic, political and military power would not be a "negative but positive factor" (Shanahan) The United States have seen China as a strategic threat and an economic competitor. Therefore, they attempted quickly to establish a tripartite pact aimed at stopping China and forcing them to accept American political and economic domination. This change in US foreign policy was unfavorable for Australia, and in particular for Prime Minister Howard, because as a result of good contacts with China, Australia gained economically. tripartite strategic dialogue

Australia's relations with India were another important aspect of Australia's foreign policy. This is why the visit of John Howard to India, after the visit of Bush and secretary Condolelezza Rice in 2006, was closely watched by Australian society. During the visit to India, the American side fully accepted India's possession of nuclear weapons and the expansion of nuclear industry. (Bajkowski, Wizyta sekretarz Condolezzy Rice, 6). It seemed strange that India could benefit from this without joining the international NPT (Non-Proliferation Treaty) (Bajkowski, Wizyta sekretarz Condolezzy Rice, 6). This was positive news for Australia due to the fact that Australian energy resources (uranium ore, natural gas, oil and coal) could be sold to India. However, the deterioration of US-Chinese relations and Rice's emphasis on non-compliance with human rights in China adversely affected AustralianChinese relations. Despite Australian decisions that were not entirely favorable for America, Australia remained a loyal ally of the United States. Australia did not take part in the campaign to stop China from violating human rights, because relations with China for the Australian economy were very important. The importance of these relations was just as important for Australia as maintaining good relations with the US (Bajkowski, Howard w Chinach, 6).

The role of Australia as a sheriff for the US is part of the United States' strategy to stop China. Australia's role in Afghanistan and Iraq is part of this strategy and this is how it should be read. The military intervention of Australia in relation to its northern neighbors, including Indonesia and Papua New Guinea, and part of the Western Pacific should be read as a stage of war against terror or against drug smuggling and smuggling of people and as part of the struggle for freedom and democracy in the region (Paul 2012). That is why Australia is seriously involved in armaments, which is recorded in the 2009 Defence White Paper White Defense Defensive Australia Paper in the Asia Century Force 2030. Defense White Paper mentions China as a potential enemy. Consequently, the Australian document calls for a doubling of the sea fleet resources and the purchase of about 100 fighters from the United States. The intention of Defense White Paper was also to strengthen the military equipment and equipment of great importance to fight in the event of a war accident in Asia (Paul 2012). 
Against this background, military and intelligence relations with the United States have improved. As a result, weapons and technology resources have been released that may flow from USA to Australia. Cooperation was also aimed at militarizing space and Australia's playing an important role in the US missile program. In connection with the above, Australia has a military communication center in Pine Gap and Jindalee, where very efficient and large-scale radars are placed. These locations also serve US and British intelligence to exchange information on the location of missiles constructed in the Asia-Pacific region. It may be interesting to note that the communication center in Pine Gap in central Australia is served by persons employed under a contract with the CIA. They control flights of possible missiles and provide information on their possible detention or destruction. This center is also observing operations carried out with American drones in Afghanistan, Pakistan and other parts of the region (Department of Defence).

Another form of cooperation are American military bases in Australia - in this way modern technology is combined with combat skills. According to Philip Dorling of the Australian Defense Force Academy, it is currently impossible for Australia to be a completely neutral state if the United States is involved in any war. Another American base located in Exmouth, Western Australia is supposed to spy on Chinese satellites. In this way, all Australian military operations are coordinated with the US (Department of Defence).

The relations between Australia and the United States have been formalized under the ANZUS Treaty and the Free Trade Agreement between Australia and the United States. According to a BBC World Service survey from 2014, 44\% of Australians had a generally positive view of the United States and a $46 \%$ negative attitude. There is no other similar research available from that time relating to Australia on the American side but in 2012, according to the US report "Global Leadership" $55 \%$ of Australians have confirmed the leadership of the United States in today's world, $21 \%$ denied it and $24 \%$ were uncertain. In another survey from $2016,60 \%$ of Australians supported US leadership. In the following year 2017, a survey conducted by the Lowy Institute showed that $77 \%$ consider the United States as a country important from the point of view of security. However, recently during the presidency of Donald Trump, New Zealand is considered to be the best friend, not Australia. Research from 2018 also showed that $70 \%$ of Australians believe that the current President Donald Trump does not act responsibly, only $30 \%$ thought that he could ensure security. For comparison, Barack Obama enjoyed great trust from society in terms of security (Lewis).

The new chapter of the relationship between Australia and the United States opened with the new President in the White House from 2017. Immediately after the swearing-in of President Trump there were negative comments in Australia, some even alarming.Donald Trump, also to confirm his credibility, started his earlier announced controversial policy. He started with forbidding immigration of 
refugees to the USA from Syria and also all people from Iraq, Sudan, Libia, Somalia and Yemen (Bajkowski, Nowa era w USA, 6). In this context there was a talk with the Prime Minister of Australia. One of the most important conversations was of Trump with Australian Prime Minister Malcolm Turnbull. Donald Trump had different telephone conversation with European leaders as well, but this conversation lasted 25 minutes (Bajkowski, Nowa era w USA, 6).

The main subject concerned economic immigrants who for three years were in two places in Nauru and Manus Island. As agreed with President Barak Obama, the United States pledged to accept 1,250 people from this group of 2000. However, President Trump opposed and believed that this was inconsistent with his adopted policy. He said that more and more bombers and terrorists could come out of these people, he believed that the United States had become "a rubbish dump". Prime Minister Turnbull explained that people arriving by boat were to be sent back. In the initial phase of the conversation Trump stated that Turnbull is: "You are worse than I am". (Lewis). Trump did not accept these 1250 people. There seemed to be a big difference between Trump's policy and the policy of vice-president Mike Pence and former President Obama concerning immigration (Zurcher).

In July 2017 President Trump met Prime - Minister Turnbull at a G-20 meeting in Hamburg where they had a successful talk. Due to Washington's new policy, not only the relationship with the USA was important but also with China. Therefore the USA asked Australia in 2016 to choose if cooperation with China was more important or cooperation with the USA(Trans-Pacific Partnership TPP) (Bajkowski, Obrady G-20, 6). In this situation it seems that Australia will support, without participation of the USA, the Chinese regional economic-trade partnership "Asia-Pacific", (John Moll). Observers say that this will only strengthen China and increase Australian export to China (Bajkowski, Wizyta premiera ChRL, 6).

In 2018, Prime Minister Trump's visit to Australia was initially planned in connection with Asia-Pacific Economic Co-operation in Papua New Guinea on 17 and 18 November 2018, however, it did not come to fruition.

The planned meeting may take place before the summit in the following cities: Sydney, Canberra and Cairns. President Trump would also be in Brisbane. That would be Trump's first visit as a president in Australia (The Australian).

One of the purposes of this visit, among others is the case of filling the position of the US ambassador in Australia. It is speculated that the future ambassador in Australia may become the head of the White House staff John Kelly - general United States Marine Corps). From 2012 to 2016 he dealt with the leadership of the Southern Command in Florida, and in 2003 he was appointed a Marine Colonel promoted to the rank of Brigadier General (Kelly).

Rumors say John Kelly would leave the White House in the coming months, but nothing is certain. White House spokeswoman Sarah Huckabee-Sanders spoke 
about Kelly's candidacy that they are "fake news." Australia still has no ambassador from the United States since John Berry left this position in October 2016 during the term of Barack Obama. One of the candidates was Commander Harry Harris but in April 2018 he became an ambassador in North Korea and was deeply involved in talks on the denuclearization of the region (Kehoe). Also one of the candidates for this position was the Republican Senator Bob Corker, who in May 2018 rejected the proposal to become the US ambassador in Canberra (Zengelere). A serious candidate for this position is Charge d'Affaires James Carouso. Carouso has good contacts with high officials in Canberra and at the same time with the government of the former Australian Prime Minister Turnbull (Kehoe).

In the context of this article, attention has been paid to mutual visits since the beginning of 2000. And so, John Howard in 2000-2006 made eight visits to the United States, the first visit was combined with visits to Japan. And the third one was during the attack on the World Trade Center in New York. Howard's successor, Kevin Rudd, visited Washington twice in 2008-2009, and Prime Minister Julia Gillard was three times in the United States in the years 2011-2012. Tony Abbott was once in Washington with President Obama in 2014. By contrast, Australian Prime Minister Malcolm Turnbull has been three times in the United States since 2016 (Wikipedia). In the last visit in Washington the now ex Prime - Minister Turnbull was in February 2018. The delegation consisted of political leaders and business people. It was important for the economic and political strategy for the coming years in Australia (Bajkowski, Komentarz E. Bajkowski, 6).

Donald Trump often took part in international summits ASEM in Tokyo, Seoul, Beijing and Manilla. The personal meetings with Prime -Minister Turnbull and Foreign Minister Julie Bishop were good (Bajkowski, Międzynarodowe szczyty $i$ konsultacje, 6). Canberra had many achievements Trump declared that Australia will be one of the three countries which export steel and aluminum which will not have to pay high duty $25 \%$ for steel and less duty for aluminum (Bajkowski, USA dwa pomyślne wydarzenia, 6). To sum up the governing period of Trump during the governing by Turnbull was successful in spite of certain unpredictability of the American President.

\section{Conclusions}

It should be emphasized that Australia supports the US policy, and its visible sign is the provision of an Australian contingent, territorial waters and airspace for the military needs of the United States. Among other things, it is not only about security, but about controlling China. Since the Second World War, cooperation and interdependence between Australia and the United States have tightened. Relations with the United Kingdom gradually became looser, also because England 
has entered European structures. The 21st century and events related to terrorism have further influenced the exchange of information and commitment to the fight against terrorism. American influence is a decisive factor for Australia's identity and policy. As for Trump's policy towards Australia, it should be emphasized that it does not differ significantly from the main policy direction of the US President. Trump wants to make his country independent, but he forgets about strong economic ties and other close partners. On the other hand, in close relationships, Trump is directly in contact with the Australian leaders, but the translation of this proximity is already worse. The United States for Trump is a lot of trouble and is not a full partner as it was before, where presidents adhered to standards and rules that take into account the needs of the partner. To help with problems with immigrants or fill the US ambassador in Australia.

\section{Works Cited}

Address to the nation. "Sydney Morning Herald", 20.03.2003, pp. 1-23.

Bajkowski, E. Emisariusz Busha? "Tygodnik Polski”, 2.07.2002, pp. 1-16.

Bajkowski, E. Forum Pacyfiku. “Tygodnik Polski”, 7.08.2002, pp. 1-16.

Bajkowski, E. Howard w Chinach. "Tygodnik Polski", 15.03.2006, pp. 1-16.

Bajkowski, E. Komentarz E. Bajkowskiego. “Tygodnik Polski”, 28.02.2018, pp. 1-16.

Bajkowski, E. Komentarze. "Tygodnik Polski”, 29.03.2017, pp. 1-16.

Bajkowski, E. Masowe demonstracje. “Tygodnik Polski”, 19.02.2003, pp. 1-16.

Bajkowski, E. Międzynarodowe szczyty i konsultacje. “Tygodnik Polski”, 29.11.2017, pp. 1-16.

Bajkowski, E., Nowa era w USA? “Tygodnik Polski”, 1.02.2017, pp. 1-16.

Bajkowski, E. Obrady G-20. “Tygodnik Polski”, 12.07.2017, pp. 1-16.

Bajkowski, E. Premier leci do Londynu. "Tygodnik Polski", 25.09.2002, pp. 1-16.

Bajkowski, E. Spotkanie w Waszyngtonie. "Tygodnik Polski”, 8.05.2002, pp. 1-16.

Bajkowski, E. Stanowisko Howarda. "Tygodnik Polski”, 29.01.2003, pp. 1-16.

Bajkowski, E. Trzy zasadnicze tezy. "Tygodnik Polski”, 19.02.2003, pp. 1-16.

Bajkowski, E. USA: dwa pomyślne wydarzenia. "Tygodnik Polski”, 14.03.2018, pp. 1-16.

Bajkowski, E. Wizyta premiera ChRL. “Tygodnik Polski”, 29.03 2017, pp. 1-16.

Bajkowski, E. Wizyta sekretarz Condolezzy Rice. "Tygodnik Polski”, 15.03.2006, pp. 1-16.

Blumenthal, D. Alliance takes diverse China roles. "The Australian", 2.05.2005, pp. 1-23.

Bell, R. Extreme allies: Australia and the USA, [in:] J. Cotton, J. Ravenhill, Trading on alliance security-Australia in world affairs 2001-2005, South Melbourne 2007. 
Department of Defence, Australian Government, Australia US Treaty on Defense Trade Cooperation, Canberra 2010.

Eccleston, R. Bush war call pledge to Howard. "The Australian", 21.04.2004, pp. 1-23.

Gurry, M. Issues in Australian Foreign Policy. "Australian Journal of Politics and History", no. 49(2) (2003), pp. 1-30.

Haliżak, E. Stosunki międzynarodowe w regionie Azji i Pacyfiku, Warszawa 1999.

Historia Powszechna, L. Serafini (ed.), Novara 2008, p. 587.

Howard commits troops to war. "Sydney Morning Herald", 18.03.2003.

Industrial expansion plans for Australia. "The Canberra Times", 20.05.1946, pp. 1-15.

Kehoe, J. John Kelly 'wildcard' for rump,s Australia ambassador (April, 2017). Web. 27 July 2018, https://www.afr.com/news/politics/national/john-kelly-wildcard-for -trumps-australia-ambassador-20180628-h12i8.

Kitney, G. Howard's commitment candour lacking. "Sydney Morning Herald", 19.04.2003, pp. 1-30.

Lewis, P. Trump drives Australian trust in US to all - time low (Jun, 2018). Web. 11 September 2018, https://www.theguardian.com/australia-news/2018/jun/20/ trump-drives-australian-trust-in-us-to-all-time-low.

Meaney, N. Japan and Australia's foreign policy, 1945-1952. "Discussion Papers", Sydney 2000.

Mofa (March, 2018). Web. 1 March 2018, http://www.mofa.go.jp/region/asia-paci/ australia/joint0603.html.

Mofa (September, 2018). Web. 12 March 2018, http://www.mofa.go.jp/announce/ announce/2007/7/1174404_830.html.

Moll, J. (May, 2018). Web. 10 September 2018, https://zmianynaziemi.pl/wiadomosc/ australia-musi-wybrac-miedzy-chinami-usa-powiedzial-zastepca-szefa-sztabuus-army.

O'Keefe, M. Australia and Fragile States in the Pacific. A research agenda, La Trobe 2010.

Paul, E. Neoliberal Australia and US imperialism in East Asia. Hampshire 2012.

Shanahan, D. US understands our China dilemma. "The Australian", 16-17.07.2005, pp. 1-30.

The Australian (May, 2018). Web. 18 July 2018, www.news.com.au/national/ us-president-donald-trump-may-visit-australia-in-november/newsstory/ a6ce3b25078f0a33a6e64d ce66756ac0.

US keen on Japanese ties with Australia. "The Australian”, 2005, (Defence supplement), pp. 1-15.

Wikipedia (September, 2018). Web. 11 September 2018, https://en.wikipedia.org/wiki/ Australia\%E2\%80\%93United_States_relations.

Wilanowski, S. Japonia - społeczeństwo, ekonomia, polityka. Olsztyn 1974. 
Zengerle, P. Senator Bob Corker declines Trump offer to be ambassador to Australia (September, 2018). Web. 27 July 2018, www.smh.com.au/world/north-america/ senator-bob-corker-declines-trump-offer-to-be-ambassador-to-australia20180522-p4zgpm.html.

Zurcher, A. (February, 2017). Web. 5 September 2018, www.bbc.com/news/av/ world-us-canada-38835806/trump-unapologetic-on-tough-phone-calls.

Mieczysław Sprengel - professor at the Adam Mickiewicz University in Poznan, employed at the Faculty of Law and Administration. He received his doctorate based upon his work Polish emigration to Australia in the years 1980-200o. He was promoted academically at SGH Warsaw School of Economics in Warsaw in 2013 upon his scientific achievements and publications. He is a member of the Cracow Asia and Pacific Association. He has visited Australia for scientific purposes many times. In his research work he focuses on international economy, international relations and social-economic problems in the countries of Asia and Pacific. Another point of his interest is the economic and political history of Australia and the question of emigration. He has written many scientific articles, doctorates reviews and a few monographs. 